NASA/CR-2002-211757

ICASE Report No. 2002-24

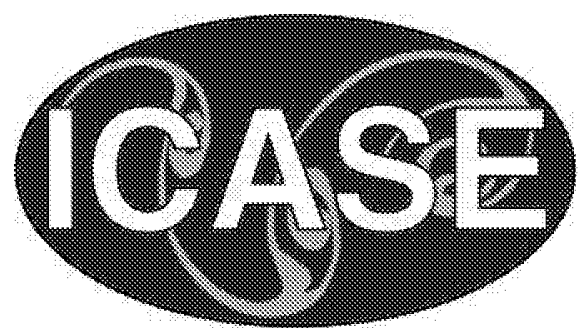

\title{
Progressive Failure Studies of Stiffened Panels Subjected to Shear Loading
}

Damodar R. Ambur

NASA Langley Research Center, Hampton, Virginia

Navin Jaunky

ICASE, Hampton, Virginia

Mark W. Hilburger

NASA Langley Research Center, Hampton, Virginia 


\section{The NASA STI Program Office . . . in Profile}

Since its founding, NASA has been dedicated to the advancement of aeronautics and space science. The NASA Scientific and Technical Information (STI) Program Office plays a key part in helping NASA maintain this important role.

The NASA STI Program Office is operated by Langley Research Center, the lead center for NASA's scientific and technical information. The NASA STI Program Office provides access to the NASA STI Database, the largest collection of aeronautical and space science STI in the world. The Program Office is also NASA's institutional mechanism for disseminating the results of its research and development activities. These results are published by NASA in the NASA STI Report Series, which includes the following report types:

- TECHNICAL PUBLICATION. Reports of completed research or a major significant phase of research that present the results of NASA programs and include extensive data or theoretical analysis. Includes compilations of significant scientific and technical data and information deemed to be of continuing reference value. NASA's counterpart of peer-reviewed formal professional papers, but having less stringent limitations on manuscript length and extent of graphic presentations.

- TECHNICAL MEMORANDUM. Scientific and technical findings that are preliminary or of specialized interest, e.g., quick release reports, working papers, and bibliographies that contain minimal annotation. Does not contain extensive analysis.

- CONTRACTOR REPORT. Scientific and technical findings by NASA-sponsored contractors and grantees.
- CONFERENCE PUBLICATIONS. Collected papers from scientific and technical conferences, symposia, seminars, or other meetings sponsored or cosponsored by NASA.

- SPECIAL PUBLICATION. Scientific, technical, or historical information from NASA programs, projects, and missions, often concerned with subjects having substantial public interest.

- TECHNICAL TRANSLATION. Englishlanguage translations of foreign scientific and technical material pertinent to NASA's mission.

Specialized services that complement the STI Program Office's diverse offerings include creating custom thesauri, building customized data bases, organizing and publishing research results . . . even providing videos.

For more information about the NASA STI Program Office, see the following:

- Access the NASA STI Program Home Page at http://www.sti.nasa.gov

- Email your question via the Internet to help@sti.nasa.gov

- Fax your question to the NASA STI Help Desk at (301) 621-0134

- Telephone the NASA STI Help Desk at (301) 621-0390

- Write to: NASA STI Help Desk NASA Center for AeroSpace Information 7121 Standard Drive Hanover, MD 21076-1320 
NASA/CR-2002-211757

ICASE Report No. 2002-24

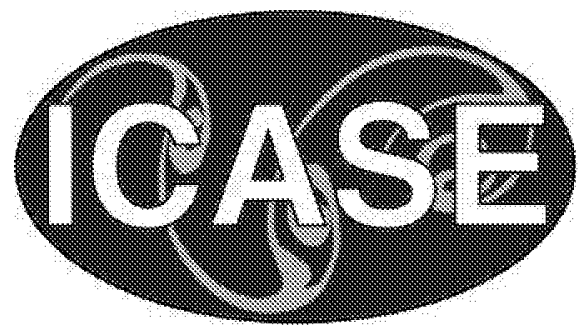

\section{Progressive Failure Studies of Stiffened Panels Subjected to Shear Loading}

Damodar R. Ambur

NASA Langley Research Center, Hampton, Virginia

Navin Jaunky

ICASE, Hampton, Virginia

Mark W. Hilburger

NASA Langley Research Center, Hampton, Virginia

ICASE

NASA Langley Research Center

Hampton, Virginia

Operated by Universities Space Research Association 
Available from the following:

NASA Center for AeroSpace Information (CASI)

7121 Standard Drive

Hanover, MD 21076-1320

(301) 621-0390
National Technical Information Service (NTIS)

5285 Port Royal Road

Springfield, VA 22161-2171

(703) $487-4650$ 


\title{
PROGRESSIVE FAILURE STUDIES OF STIFFENED PANELS SUBJECTED TO SHEAR LOADING
}

\author{
DAMODAR R. AMBUR*, NAVIN JAUNKY ${ }^{\dagger}$, AND MARK W. HILBURGER ${ }^{\ddagger}$
}

\begin{abstract}
Experimental and analytical results are presented for progressive failure of stiffened composite panels with and without a notch and subjected to in-plane shear loading well into their postbuckling regime. Initial geometric imperfections are included in the finite element models. Ply damage modes such as matrix cracking, fiber-matrix shear, and fiber failure are modeled by degrading the material properties. Experimental results from the test include strain field data from video image correlation in three dimensions in addition to other strain and displacement measurements. Results from nonlinear finite element analyses are compared with experimental data. Good agreement between experimental data and numerical results are observed for the stitched stiffened composite panels studied.
\end{abstract}

Key words. composite structures, progressive failure, ply damage mode, buckling, postbuckling, video image correlation

Subject classification. Structural Mechanics

1. Introduction. The use of composite materials for aircraft primary structures can result in significant benefits on aircraft structural cost and performance. Such applications of composite materials are expected to result in a 30-40 percent weight savings and a 10-30 percent cost reduction compared to conventional metallic structures. However, unlike conventional metallic materials, composite structures fail under different failure modes such as matrix cracking, fiber-matrix shear failure, fiber failure, and delamination. The initiation of damage in a composite laminate occurs when a single ply or part of a ply in the laminate fails in any of these failure modes over a certain region of the structure. The initiation of damage does not mean that the structure cannot carry any additional load. The residual load bearing capability of the composite structure from the onset of material failure or initiation of damage to final failure can be quite significant. This may be due to the fact that some failure modes may be benign and not degrade significantly the performance of the overall structure. It is at the final failure load that the structure cannot carry any further load. Accurate determination of failure modes and their progression helps either to devise structural features for damage containment or to define fail-safe criteria. Therefore, it is important to understand the damage initiation and progression in composite structures subjected to combined loading conditions.

A summary of the past work in progressive failure studies for the type of structure analyzed and the loading condition is presented in Ref [1]. In 1987, Talreja [2], Allen et al. [3], and Chang and Chang [4], independently proposed progressive failure models that describe the accumulation of damage in a composite laminate by a field of internal state variables. Also in the same year, progressive failure analyses were presented in References [5] and [6]. The summary indicates that nonlinear geometric effects were not considered initially. However material nonlinearity was considered in References $[4,7]$ and [8]. Englestad et al. [9] were among the first researchers to consider nonlinear geometric effects and subsequently a postbuckling problem

\footnotetext{
${ }^{*}$ Head, Mechanics and Durability Branch, NASA Langley Research Center, Hampton, VA 23681-2199

†Senior Staff Scientist, ICASE, Hampton, VA 23681-2199. The research was supported by NASA Langley Research Center under NASA Contract No. NAS1-97046 while in residence at ICASE, NASA Langley Research Center, Hampton, VA 236812199.

${ }^{\ddagger}$ Aerospace Engineer, Mechanics and Durability Branch, NASA Langley Research Center, Hampton, VA 23681-2199
} 
with progressive failure. Experimental corelation with progressive failure analyses were attempted at mostly coupon level. Comparison of progressive failure analyses with experimental data for structures of realistic size was attempted in Reference [9] and later in References [10] and [11]. Recently in References [15] and [16] experimental corelation with progressive failure analyses for stiffened panels were presented. This work was primarily on thick-skin composite panels which do not buckle before failure. Barannski and Biggers ([17]) used progressive failure analyses to show that the failure and buckling load of composite panels subjected to compression can be enhanced by appropriate stiffness tailoring. Progressive failure analyses of panels presented in References $[12,13,14]$ and $[18]$ indicate that progressive failure analyses can be used to better assess the load carrying ability of a structure at an advanced design level.

Although postbuckling analyses results have been compared extensively with experimental studies by many researchers, work in progressive failure analyses for nonlinearly deformed structures subjected to combined loading is lacking. The objective of this paper is to present results from progressive failure studies of composite panels that undergo large deformations prior to damage initiation and growth when subjected to inplane shear loading. Another objective is also to compare strain fields obtained from progressive failure analyses with experimental strain fields obtained using a full-field measurement technique at various load levels. Stiffened panels were designed and fabricated at NASA Langley Research Center to elicit the desired response for buckling and failure at design load levels.

The failure analysis is described first followed by a presentation and discussion of the numerical and experimental results for the stiffened panel response and failure.

2. Failure Analysis. Failure modes in laminated composite panels are strongly dependent on ply orientation, loading direction and panel geometry. There are four basic modes of failure that occur in a laminated composite structure. These failure modes are; matrix cracking, fiber-matrix shear failure, fiber failure which could be either fiber breakage or fiber buckling, and delamination. Delamination failure, however, is not included in the present studies since the stiffened panel investigated in this paper is made of through-the-thickness stitched material. In order to simulate damage growth accurately, the failure analysis must be able to predict the failure mode in each ply and apply the corresponding reduction in material stiffnesses. The failure criteria included in the present analyses are those proposed by Hashin [19]. The progressive failure assessment and implementation approach are discussed in References [1] and [16]. For completeness, the progressive failure assessment and implementation approach are summarized below.

To simulate the above failure modes, the elastic properties are made to be dependent on three field variables, $F V 1$ through $F V 3$. The first field variable represents the matrix failure, the second the fibermatrix shearing failure, and the third the fiber failure. The values of the field variables are set to zero in the undamaged state. After a failure index has exceeded 1.0, the associated user-defined field variable are set to 1.0. The associated field variable then continues to have the value of 1.0, even though the stresses may reduce to values lower than the failure stresses of the material. This procedure ensures that the damaged material does not heal. The mechanical properties in the damaged area are reduced appropriately, according to the property degradation model defined in Table 1 . The field variables can be made to transit from 0 (undamaged) to 1 (fully damaged) instantaneously. Hence the material degarde instantaneously according to Chang and Lessard's degradation model [7] which is used in the present study. The finite element implementation of this progressive failure analysis was developed for the ABAQUS structural analysis program using the USDFLD user-written subroutine [20,21]. The development of the user-written subroutine is further discussed in References [1] and [16]. 
3. Numerical Examples. Results are presented for two stiffened panels subjected to in-plane shear loading. The skin and stiffener elements of the panel are made of one or more pre-kitted stacks of AS4/35016 graphite-epoxy with $[45 /-45 / 0 / 90]_{s}$ stacking sequence. The first panel has a machined notch along one of its diagonals as shown in Figure 1, whereas the second panel is undamaged. The skin is made up of one prekitted stack, the stiffener flange is made up of two stacks and the stiffener blades are made up of three stacks, respectively. The panel is stitched together using kevlar threads throughout the skin, skin/stiffener flange regions, and the stiffeners. The cured thickness of each of the plies is $0.0059,0.01236$, and 0.00334 inches for the $\pm 45,0$, and 90-degree orientation, respectively. Each prekitted stack is approximately 0.055-inches thick and the nominal material properties, ply thickness fraction and ply strength of each ply orientation are presented in Table 2.

A picture frame is used to load the stiffened panel in in-plane shear. The test section of the stiffened panel is 22.5-in. by 22.5-in. and the members of the picture frame are 4.0-in. wide and 3.35-in. thick. The fixture is made of steel. The stiffened panel assembled with the steel doubler plates is shown in Figure 1. A schematic of the picture frame test fixture is shown in Figure 2. In the finite element model, nodes on each member of the picture frame were constrained for the out-of-plane displacement. Pin joint consists of two co-incident nodes tied in a multi-point constraint at the four corners of the panel. The displacements of the dependent node are made the same as that of the independent node, but the rotations are excluded from the multi-point constraints. The independent node diagonally opposite to the loading pin is constrained for axial and transverse displacements. At the loading pin, applied displacement equal in magnitude in the axial and transverse directions at the independent node simulates the loading condition. The test section is modeled using the ABAQUS four node, reduced integration, shear-deformable S4R element [21]. The members of the picture frame are modeled using ABAQUS four node shear-deformable S4 element [21].

3.1. Stiffened panel with a notch. The stiffened panel with a 5 -in.-long notch was tested and results from a progressive failure analysis were compared were compared with experimental results to validate the progressive failure analysis methodology. A finite element model of the panel is shown in Figure 3 . This model consists of 3,925 nodes and 3,769 elements. The size of the smallest elements is $0.02 \mathrm{in}$. by $0.05 \mathrm{in}$. Measured geometric imperfection was included in the model for the skin and flange elements.

The global response of the panel can be described by the variation of the applied load and the displacement of the loading pin of the picture frame test fixture. The experimental load versus displacement of the loading pin in the test section in the loading direction is presented in Figure 4. Also shown in Figure 4 is the load versus extension of the independent node of the loading pin generated from the Progressive Failure Analyses (PFA) results. The PFA results are in good agreement with the experimental results for most part of the loading range. While the panel failed catastrophically during the test, analysis results show a gradual decrease in the load before the panel fails catastrophically. Matrix cracking damage (FV1) is initiated at 9.137 kips, fiber-shear matrix is initiated at 10.477 kips, and fiber failure is initiated at 11.145 kips as computed by the progressive failure analysis. Analytical results also indicate that damage initiated at the tip of the notch as shown in Figure 5. The final failure load as obtained by PFA is 36.53 kips compared to the load value of 37.72 kips from the experiment.

The experimental strain data at a point 5.49-in from the panel center and along the notch is compared with strain obtained from PFA simulations. This strain-gage location is 3.0-in. from the upper tip of the notch and corresponds to location $A$ as shown in Figure 5. The strains along the fiber direction, $\epsilon_{11}$, and normal to the fiber direction, $\epsilon_{22}$, on the top and bottom surfaces of the skin are shown in Figures 6 and 7 , respectively. The experimental buckling load is $2,900 \mathrm{lbs}$ whereas the predicted buckling load is $2,943 \mathrm{lbs}$. 
This panel is designed to buckle very early, and in the buckled configuration damage first initiates as matrix cracking (FV1) at a load of 9,137 lbs., which corresponds to a highly postbuckled state. Therefore, the damage initiated in the postbuckling regime as designed, and damage progression occurs while the structure deformed non-linearly. The measured and predicted strains are in good agreement.

The experimental strain data at a point close to the panel center and the notch which corresponds to location B (see Figure 5) is compared with strain obtained from PFA analysis. The strain along the fiber direction, $\epsilon_{11}$, on the top and bottom surfaces of the skin is shown in Figure 8. The measured and predicted strains are in good agreement for most of the loading range.

The outer skin segments around the skin segment with the notch buckle at a higher load than the skin segment with the notch. Experimental strain normal to the fiber direction, $\epsilon_{22}$, on the top and bottom surfaces of the skin at Location D (see Figure 5) are compared in Figure 9 with strain results from PFA analysis. Buckling of the segments occurs after damage initiation. The analytical buckling load of the skin segments outside the stiffeners is approximately 13,600 lbs, whereas, the experimental buckling load is approximately $13,500 \mathrm{lbs}$. The discrepency between the predicted strains and measured strains after buckling could be due to the skin thickness in that segment being thinner than the nominal thickness.

Analytical out-of-plane displacement contour plots are compared with experimental contour plots from moire fringe interferometry in Figures 10 and 11, respectively, at a few selected loads. The selected loads for the analytical contour plots are not exactly the same as the selected loads for the experimental contour plots, since they were recorded at different load intervals. However, the loads are close to each other, as shown in Figures 10(a) through 10(f) and Figures 11(a) Figure 11(f). The analytical contour plots have the same trend for deformation as the experimental contour plots and are in good qualitative agreement. Comparing Figure 10(a) with Figure 11(a), both the analytical contour plot and the experimental contour plot indicate that the skin segment with the notch has buckled at their corresponding loads. Figure 10(c) and Figure 11(c) also indicate that all the skin segments have already buckled at their corresponding loads.

Analytical damage plots for matrix cracking, fiber-matrix shear, and fiber failure are compared in Figure 12 with damage as observed visually. Figures 12(a) through 12(c) show matrix cracking, fiber-matrix shear, and fiber failure damage plots, respectively, in some selected plies within the skin. The dark contours represent damaged areas. Figure 12(d) shows a picture of the panel after failure. The cracks that propagated from the tips of the notch when the panel failed catastrophically can be seen from this figure. The location of the observed cracks match the analytically predicted damaged areas in Figure 12(a) through 12(c) which also originated from the tips of the notch.

3.2. Stiffened panel without a notch. The results for the stiffened panel without a notch are presented in this section. Video Image Correlation in 3-D (VIC-3D) [22] was used on the skin side of the panel to provide the full-field displacement results of the test section. Figure 13 shows the experimental setup of the VIC-3D arrangement with respect to the test panel and the loading machine. More information about VIC-3D can be found in reference [22].

A finite element model of the panel is shown in Figure 14. This model consists of 9,673 nodes and 9,568 elements (Fig. 14(a)). The size of the smallest element is 0.10 in. by 0.10 in. Various skin segments in between the stiffeners and the flanges in the model are shown Figure 14(b). Thickness measurements were made, and the average thickness value for each skin segment was computed and input to the finite element model. These average thicknesses are given in Table 3. Measured geometric imperfection was also included in the model for the skin and flange elements. 
Two progressive failure analyses of the panel were conducted using the finite element model described above. In the first PFA (PFA-1) the panel was loaded until complete failure. Based on PFA-1, it was found that matrix cracking initiated at $11.32 \mathrm{kips}$, fiber-matrix shear initiated at $25.11 \mathrm{kips}$, and fiber failure initiated at 26.26 kips. Therefore to study the failure response of the panel, the test was conducted in three following successive runs;

1. In Run-1, the panel was loaded up to 12.0 kips and then unloaded.

2. In Run-2, the panel was loaded up to 30.0 kips and then unloaded.

3. In Run-3, the panel was loaded up to failure.

The second progressive failure analysis (PFA-2) was conducted to mimic the sequences for loading and unloading of the test. Since displacement control is used in the PFA, the displacement corresponding to 12.0 kips and 30.0 kips were obtained from PFA-1. Post-processing of PFA-2 results indicated that these displacements were very close to those obtained at 12.0 and 30.0 kips from PFA - 1 . Test results were compared with simulations from PFA-1 and PFA-2 to assess the progressive failure analysis.

The experimental load versus displacement of the loading pin of the picture frame in the loading direction is presented in Figure 15. Figure 15 also shows the corresponding analysis results for the loading pin generated from the analyses. The results from PFA-1 and PFA-2 are in good agreement with the experimental results for most of the loading range. While the panel failed suddenly and catastrophically during the test, results from both analyses suggest a gradual decrease in the load before the panel fails catastrophically. Analyses results also indicate that matrix cracking and fiber-shear matrix and fiber failure damage modes initiated at the location shown in Figure 16. There is a small difference in load-displacement response between PFA-1 and PFA-2 just before the collapse of the panel and this is due to damage accumulation in the first and second loading sequences of the analysis. The failure load predicted by PFA-1 is 43.2 kips. In PFA-2, the panel is unloaded from 30.0 kips by gradually reducing the pin displacement to zero. The reduction in panel stiffness due to damage accumulation resulted in a negative load of approximately $2000 \mathrm{lbs}$ corresponding to zero displacement. Since the load was not initialized to zero, the predicted failure load from PFA-2 is 45.1 kips. The failure load from the experiment is 44.2 kips and compares well with results from analyses.

The experimental strain data at the panel center, which corresponds to Location A (Figure 16) is compared with strain results obtained from PFA-1 and PFA-2 simulations in Figures 17(a) and 17(b), respectively. Only the strain along the fiber direction, $\epsilon_{11}$, and normal to the fiber direction, $\epsilon_{22}$, on the top surface of the skin (stiffener side) are shown in Figures 17(a) and 17(b). The experimental buckling load is 4,013 lbs. whereas the predicted buckling load is $3,980 \mathrm{lbs}$. This panel buckles very early and damage first initiates as matrix cracking (FV1) at a load of 11.32 kips which corresponds to a highly postbuckled state. Therefore the damage initiated in the postbuckling regime and progressed while the structure deformed nonlinearly. The predicted strains from PFA-1 and PFA-2 are in good agreement with the measured strains.

The experimental strain data at Location B (Figure 16) is compared in Figure 18 with strain results obtained from PFA-1 and PFA-2 simulations. Only the strain along the fiber direction, $\epsilon_{11}$, and normal to the fiber direction, $\epsilon_{22}$, on the top surface of the skin (stiffener side) are shown in Figure 18. Strain results from PFA-1 and from Run-3 of PFA-2 (Run-3(PFA-2)) are compared with the experimental results of Run-3(Exp.). It is seen that while the $\epsilon_{11}$ strains from PFA-1 and PFA-2 are in good agreement with the experimental results, the $\epsilon_{22}$ strains from the experiment are in better agreement with the PFA-2 strains than the strain results from PFA-1. This is due to PFA-2 taking into account the damage accumulation due to the strain $\epsilon_{22}$ from Run-1(Exp.) and Run-2(Exp.). 
Analytical fringe plots of the strain along the fiber direction $\epsilon_{11}$ are compared in Figures 19 through 22 with experimental fringe plots obtained from VIC-3D measurements at a few selected load levels. The blue patch shown in Figure 19(a) represents the region over which the full-field displacement data was generated. The VIC-3D measurements captured the displacement field on part of the skin segment D (Figure 14(b)) and do not include the areas close to the stiffener intersections. The strain field was subsequently calculated from the displacement field. Strain fields obtained from PFA-2 analyses are compared with strain field from VIC-3D. The strain field at approximately 11.7 kips which is just before the end of Run-1, are compared in Figure 19. These figures suggest that the strain fields results between the test and analysis compare very well. The strain field at approximately 30.0 kips, which is just before the end of Run-2, are compared in Figure 20. A strain concentration in the mid-region of the skin segment between the stiffeners and the stiffener intersection points can be seen here. The strain fields at approximately 30.0 and 44.0 kips load levels during Run-3 are compared in Figures 21 and 22. The strain contours and magnitudes suggest that there is very little difference between panel states from Run-2 to Run-3. Strain concentrations very close to the critical strain of 0.012 can be seen in Figure 22 near the stiffener intersection points. These strain concentrations are not seen in the strain field from the VIC-3D measurements did not include areas close to stiffeners intersections. Although the fringe colors corresponding to the minimum and maximum strain for the VIC-3D fringe plots and the ABAQUS fringe plots are different, in both plots the $\epsilon_{11}$ strain ranges from a minimum of 0.0 to a maximum of 0.0121 . The maximum $\epsilon_{11}$ strain level corresponds to the tensile strength along the fiber direction. Overall, it can be seen that the predicted and the experimental strain distribution and magnitude over the area of the panel are in good agreement with each other.

The analysis results suggest that damage first initiates as matrix cracking at the location shown in Figure 16 at a load of 11.32 kips within the bottom -45 and 0 degree plies. As the load is increased, fibermatrix shear and fiber failure damage initiate, at 25.11 kips and 26.26 kips respectively, at the location shown in Figure 16 within the bottom -45 degree ply. Fringe plot of matrix cracking damage at a load of approximately 30.0 kips (Run-2) in the top 0 and -45 degree plies are shown in Figure 23(a) and Figure 23(b), respectively. The red fringes indicate damage areas. At this load level, analysis results suggest that the fiber-matrix shear and fiber failure damage are still limited to the small area shown in Figure 16.

Fringe plots of matrix cracking, fiber-matrix shear, and fiber failure after final failure of the panel are shown in Figure 24 and 25. As shown in Figure 24, the matrix cracking damage in the -45 degree ply is more extensive than in the 45 and 90 degree plies. Fringe plots of fiber-matrix shear and fiber failure damage for the top -45 and 45 degree plies are shown in Figure 25. The fiber failure in the top 45 degree ply as shown in Figure 25(c) is consistent with the visually observed fiber failure damage around the top stiffener intersection in the top right corner as shown in Figure 26(a) and with the fiber failure detected by the thermogragh scan as shown in Figure 26(b). These fiber failures contributed to the catastrophic failure of the panel. Analytical fiber failure damage plot shown in Figure 27(a) at a load level of 44.1 kips (just before failure) indicates negligible damage in the top 45 degree ply at the stiffener intersection region as compared to Figure 25(c), which is a plot of fiber failure damage at 40.5 kips after the panel collapsed. This was captured by the digital video camera and is shown in Figures 27 (b) and $27(\mathrm{c})$. There is no visible fiber failure in Figure $27(\mathrm{~b})$ at 44.2 kips whereas in Figure 27(c) there is visible fiber failure damage at the same load level of 44.2 kips at which load the panel failed catastrophically. The yellow region in Figure 26(b) indicates extensive internal damage to the skin. The extensive matrix cracking as shown in Figure 24 for a few selected plies and the fiber-matrix shear and fiber failure damage as shown in Figure 25(a) and 25(b) also suggest existence of panel damage. 
4. Concluding Remarks. The results of an analytical and experimental study to evaluate the initiation and progression of damage in nonlinearly deformed stitched stiffened panels are presented. These studies are conducted for panels with and without a centrally located diagonal notch and subjected to inplane shear loading. The progressive failure methodology included matrix cracking, fiber-matrix shear, and fiber failure, but ignored delamination failure since the panels were fabricated using through-the-thickness stitched preforms. Initial geometric imperfections and, to some extent thickness imperfections were included in the finite element models. Experimental data consisted of displacement measurements, strain measurements, and strain field measurement using VIC-3D system. Damage detection after failure was attempted on the un-notched panel using a thermographic scan. Progressive failure analyses with successive loading and unloading sequences to mimic the experimental loading conditions were also performed.

For the stitched stiffened panels loaded in in-plane shear loading, the three failure modes considered in the study accurately represent the damage scenario in the postbuckling regime. The analytically determined panel response, failure modes and damage locations compare well with the experimental results. Including thickness imperfection results in a better agreement between the analytical and the experimental results. Progressive failure analysis results with sucessive loading and unloading sequences to mimick the experimental loading conditions are also in good agreement with the experimental results. It was found that these progressive failure analyses can account for the damage history from a previous loading run.

The predicted and observed damage modes from the test and analyses were in agreement for the notched panel as well as for the un-notched panel. The progressive failure analyses were able to predict the fiber failure damage mode that led to catastrophic failure of the panels.

\section{REFERENCES}

[1] D. R. Ambur, N. Jaunky, N., C. G. DÁvila, And M. W. Hilburger, Progressive Failure Studies of Composite Panels with and without Cutouts, NASA/CR-2001-211223, ICASE Report No. 2001-27.

[2] R. TAlReJA, Modeling of Damage Development in Composites using Internal Variable Concepts, Damage Mechanics in Composites, AD Vol. 12, Proceedings of the ASME Winter Annual Meeting, Boston, MA, (1987), pp. 11-16.

[3] D. H. Allen, C. Harris, and S. E. Groves, A Thermomechanical Constitutive Theory for Elastic Composites with Distributed Damage, Part I. Theoretical Development, International Journal of Solids and Structures, Vol. 23, No. 9, (1987), pp. 1301-1318.

[4] F.-K. Chang, and K. Y. Chang, A Progressive Damage Model for Laminated Composites Containing Stress Concentrations, Journal of Composite Materials, Vol. 21, Sept. (1987), pp. 834-855.

[5] A. K. Pandey, And J. N. Reddy, A Post First-Ply Failure Analysis of Composite Laminates, AIAA Paper 87-0898, Proceedings of the AIAA/ASME/ASCE/AHS/ASC 28th Structures, Structural Dynamics, and Material Conference, 1987, pp. 788-797.

[6] O. O. OchoA, and J. J. Engblom, Analysis of Failure in Composites," Composite Science and Technology, Vol. 28, 1987, pp. 87-102.

[7] F.-K. Chang, And L. B. Lesard, Damage Tolerance of Laminated Composites Containing an Open Hole and Subjected to Compressive Loadings: Part 1-Analysis, Journal of Composite Materials, Vol. 25, Jan. (1991), pp. 2-43. 
[8] I. Shahid, I., F.-K. Chang, An Accumulative Damage Model for Tensile and Shear Failures of Laminated Composite Plates, Journal of Composite Materials, Vol. 29, No. 7, 1995, pp. 926-981.

[9] S. P. Engelstad, J. N. Reddy, and N. F. Knight, Postbuckling Response and Failure Prediction of Graphite-Epoxy Plates Loaded in Compression, AIAA Journal, Vol. 30, No. 8, August 1992, pp. 2106-2113.

[10] D. W. Sleight, N. F. Knight, and J. T. WAng, Evaluation of a Progressive Failure Analysis Methodology for Laminated Composite Structures, Proceedings of the 38th AIAA/ASME/ASCE/AHS/ASC Structures, Structural Dynamics, and Materials Conference, Reston, VA, 1997, pp. 2257-2272.

[11] E. Moas, And O. H. GRtFfin JR., Progressive Failure Analysis of Laminated Composite Structure, AIAA Paper 97-1186, Proceedings of the AIAA/ASME/ASCE/AHS/ASC 38th Structures, Structural Dynamics, and Material Conference, 1997, pp. 2246-2256.

[12] S. B. Singh, A. Kumar, And N. G. R. Iyengar, Progressive Failure of Symmetrically Laminated Plates under Uniaxial Compression, Structural Engineering and Mechanics, Vol. 5, (1997), pp. 433450 .

[13] S. B. Singh, and A. Kumar, Postbuckling Response and Failure of Symmetric Laminates under In-Plane Shear, Composite Science and Technology, Vol. 58, (1998), pp. 1949-1960.

[14] L. N. B. Gummadi, And A. N. Palazotto, Progressive Failure Analysis of Composite Shells considering Large Rotations, Composite Part B, Vol. 29, (1998), pp. 547-563.

[15] D. Huang, and L. Minnetyan, Computational Simulation of Progressive Fracture in J-Stiffened Composite Shear Panels in Postbuckling Range, AIAA Paper 99-1356, Proceedings of the AIAA/ASME/ASCE/AHS/ASC 40th Structures, Structural Dynamics, and Material Conference, 1999, pp. 1353-1362.

[16] C. G. DÁvila, D. R. Ambur, and D. W. MCGowan, Analytical Prediction of Damage Growth in Notched Composite Panels Loaded in Compression, Journal of Aircraft, Vol. 37, No. 5, Sept.-Oct. (2000), pp. 898-905.

[17] A. T. Baranski, and S. B. Biggers, Postbuckling Analysis of Tailored Composite Plates with Progressive Failure, Composite Structures, Vol. 46, (1999), pp. 245-255.

[18] N. F. Knight, C. C. Rankin, and F. A. Brogan, Controlling a Nonlinear Solution Procedure During a Progressive Failure Analysis, AIAA Paper No. 2000-1460, April 2000.

[19] Z. Hashin, Failure Criteria for Unidirectional Fiber Composites, Journal of Applied Mechanics, Vol. 47, June (1980), pp. 329-334.

[20] ABAQUS User's Manual, Vol. 3, Version 5.6, Hibbitt, Karlsson, and Sorensen, Pawtucket, RI, 1996, pp. 25.2.33-1.

[21] ABAQUS Example Problems Manual, Vol. 1, Version 5.5, Hibbitt, Karlsson, and Sorensen, Pawtucket, RI, 1995, pp. 3.2.25.25-1.

[22] D. M. McGowan, D. R. Ambur, T. G. Hanna, and S. R. McNeil, Evaluating the Compressive Response of Notched Composite Panels using Full-Field Displacement, Journal of Aircraft, Vol. 38, No. 1, (2001), pp 122-129. 
TABLE 1. Dependence of material elastic properties on the field variables

\begin{tabular}{llll}
\hline \hline No failure & Matrix cracking & Fiber-matrix shear & Fiber failure \\
\hline$E_{11}$ & $E_{11}$ & $E_{11}$ & $E_{11} \rightarrow 0$ \\
$E_{22}$ & $E_{22} \rightarrow 0$ & $E_{22}$ & $E_{22} \rightarrow 0$ \\
$\nu_{12}$ & $\nu_{12} \rightarrow 0$ & $\nu_{12} \rightarrow 0$ & $\nu_{12} \rightarrow 0$ \\
$G_{12}$ & $G_{12}$ & $G_{12} \rightarrow 0$ & $G_{12} \rightarrow 0$ \\
$G_{13}$ & $G_{13}$ & $G_{13} \rightarrow 0$ & $G_{13} \rightarrow 0$ \\
$G_{23}$ & $G_{23}$ & $G_{23}$ & $G_{23} \rightarrow 0$ \\
\hline$F V 1=0$ & $F V 1=1$ & $F V 1=0$ & $F V 1=0$ \\
$F V 2=0$ & $F V 2=0$ & $F V 2=1$ & $F V 2=0$ \\
$F V 3=0$ & $F V 3=0$ & $F V 3=0$ & $F V 3=1$ \\
\hline \hline
\end{tabular}

TABLE 2. Material properties, ply thickness, and strength of each ply orientation

\begin{tabular}{llll}
\hline \hline & \multicolumn{3}{c}{ Ply orientation } \\
\cline { 2 - 4 } & $\pm 45^{\circ}$ & $0^{\circ}$ & $90^{\circ}$ \\
\hline$E_{11}(\mathrm{msi})$ & 16.15 & 16.43 & 15.97 \\
$E_{22}(\mathrm{msi})$ & 1.60 & 1.60 & 1.60 \\
$G_{12}(\mathrm{msi})$ & 0.80 & 0.80 & 0.80 \\
$G_{13}(\mathrm{msi})$ & 0.80 & 0.80 & 0.80 \\
$G_{23}(\mathrm{msi})$ & 0.40 & 0.40 & 0.40 \\
$\nu_{11}$ & 0.34 & 0.34 & 0.34 \\
\hline Thickness fraction & 0.2147 & 0.4491 & 0.1214 \\
\hline$X_{t}(\mathrm{ksi})$ & 195.75 & 218.45 & 180.00 \\
$X_{c}(\mathrm{ksi})$ & 150.00 & 150.00 & 150.00 \\
$Y_{t}(\mathrm{ksi})$ & 5.0 & 5.0 & 5.0 \\
$Y_{c}(\mathrm{ksi})$ & 31.0 & 31.0 & 31.0 \\
$S_{c 12}(\mathrm{ksi})$ & 17.5 & 17.5 & 17.5 \\
$S_{c 13}=S_{c 23}(\mathrm{ksi})$ & 4.8 & 4.8 & 4.8 \\
\hline \hline
\end{tabular}

TABLE 3. Average thickness for skin segments

\begin{tabular}{lc|lc}
\hline \hline Segment & $\begin{array}{c}\text { Thickness } \\
\text { (in.) }\end{array}$ & Segment & $\begin{array}{c}\text { Thickness } \\
\text { (in.) }\end{array}$ \\
\hline A & 0.0564 & F & 0.0637 \\
B & 0.0551 & G & 0.0556 \\
C & 0.0581 & H & 0.0547 \\
D & 0.0631 & G & 0.0533 \\
E & 0.0548 & & \\
\hline \hline
\end{tabular}




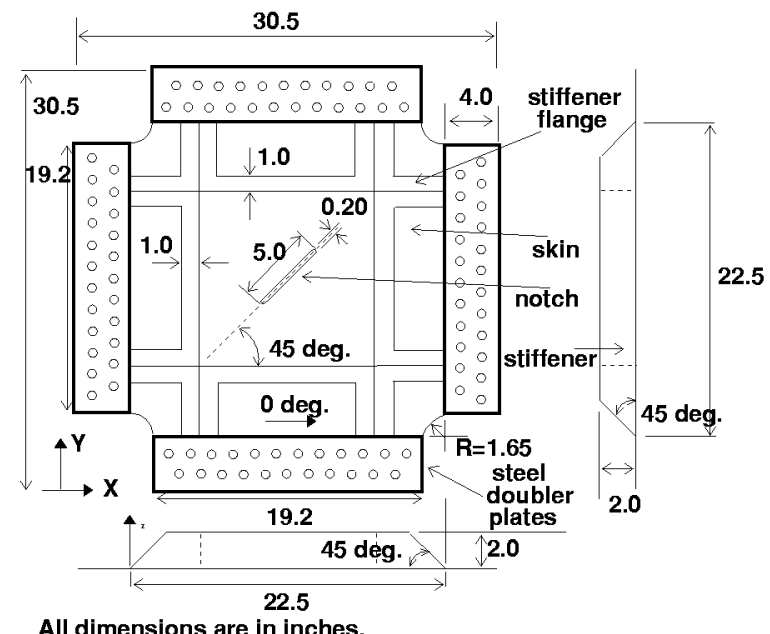

FIGURE 1. Dimensions for stiffened composite panel and plate doublers.

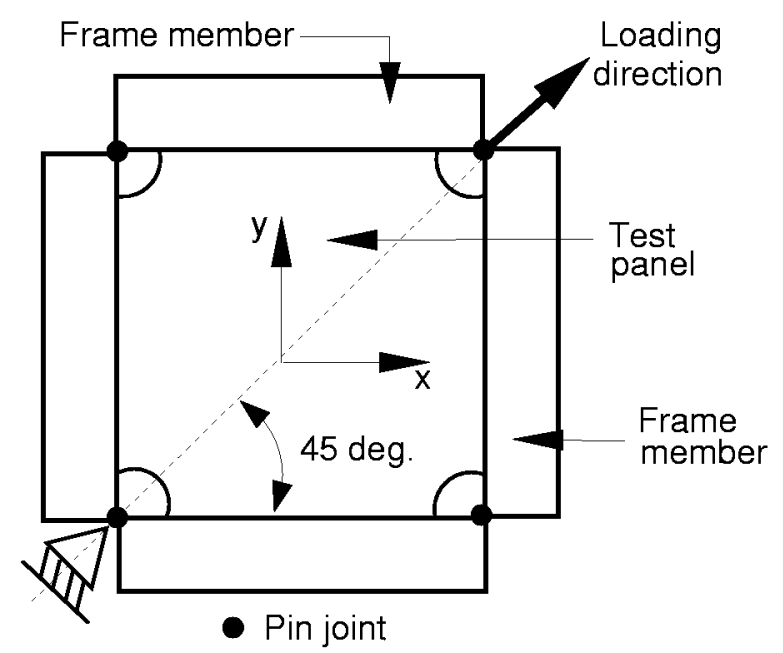

FIGURE 2. Schematic diagram of picture frame test fixture.

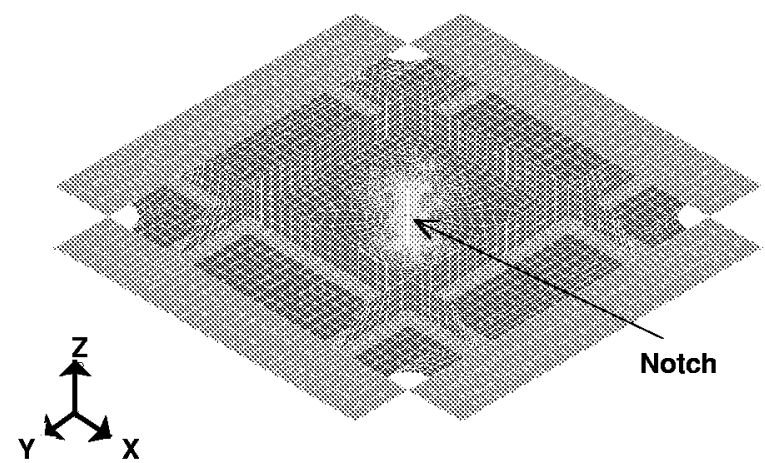

FIGURE 3. Finite element model of stiffened panel with a notch and test fixture. 


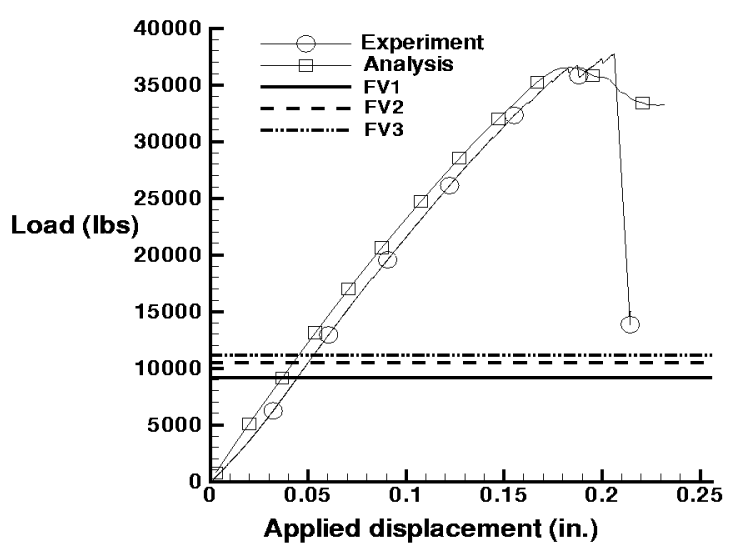

FIGURE 4. Load versus applied displacement results for the notched panel.

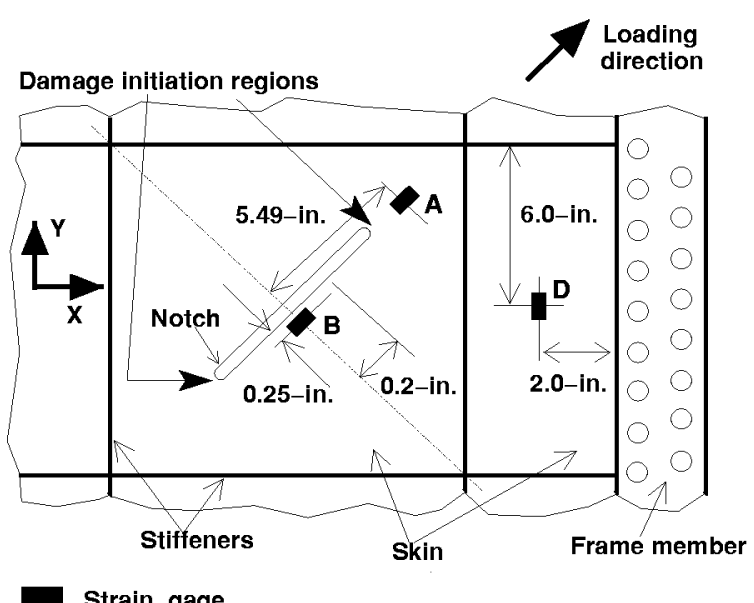

FIGURE 5. Location of some response measurement points on the stiffened panel with a notch.

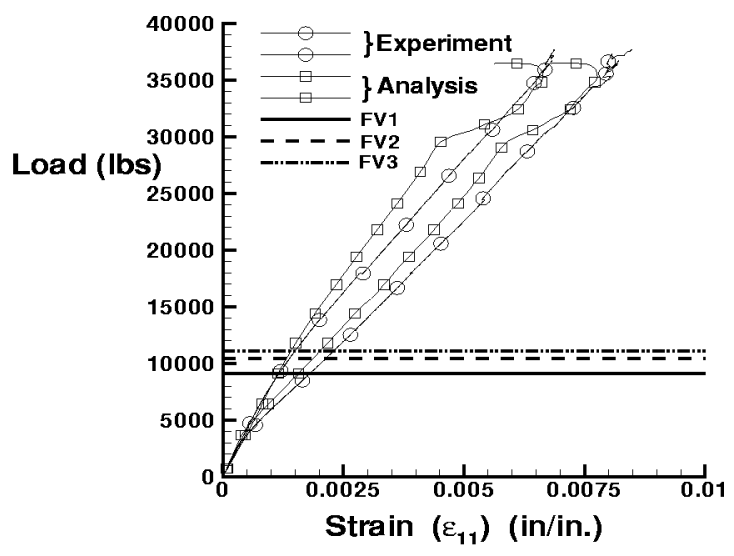

FIGURE 6. Back-to-back strain $\left(\epsilon_{11}\right)$ results at Location A for notched panel. 


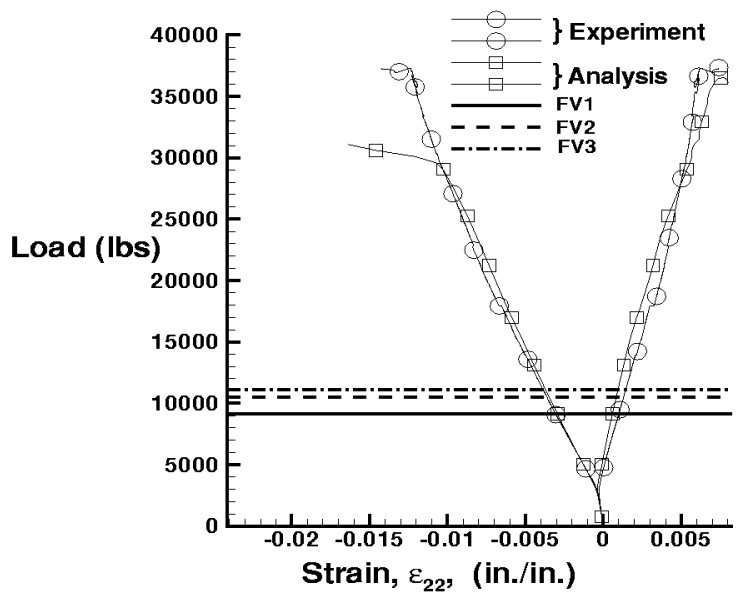

FIGURE 7. Back-to-back strain $\left(\epsilon_{22}\right)$ results at Location A (Figure 5) for the notched panel.

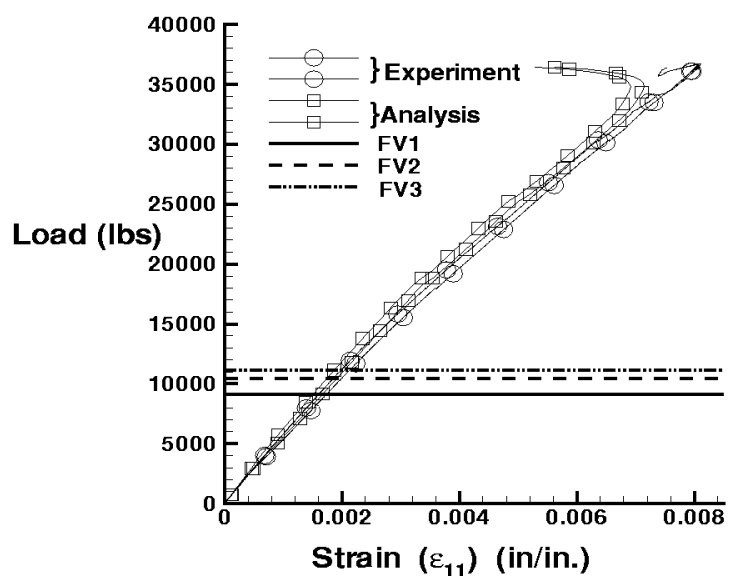

FIGURE 8. Back-to-back strain $\left(\epsilon_{11}\right)$ results at Location B (Figure 5) for notched panel.

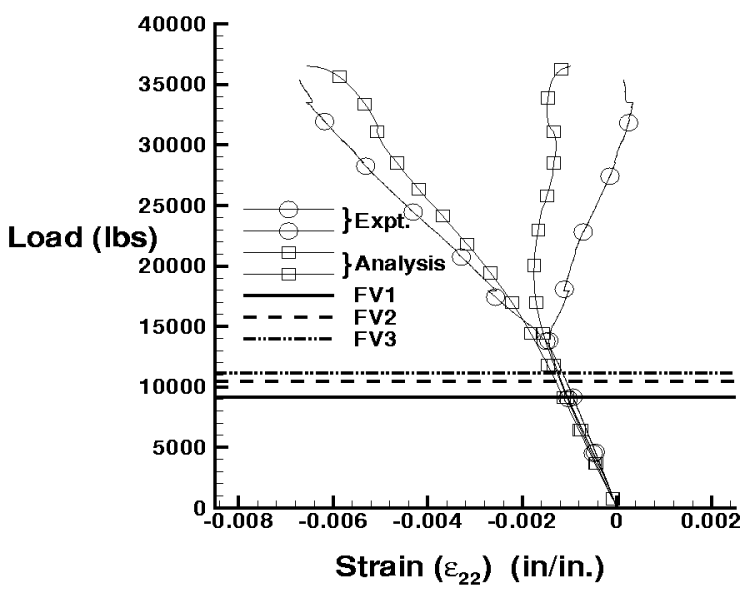

FIGURE 9. Back-to-back strain $\left(\epsilon_{22}\right)$ results at Location D (Figure 5) for notched panel. 


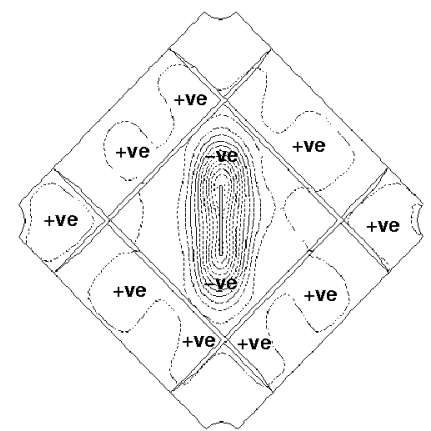

(a) $\mathrm{P}=3,670 \mathrm{lbs}$

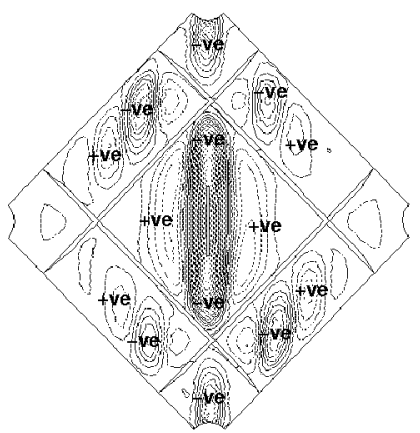

(d) $\mathrm{P}=25,809 \mathrm{lbs}$

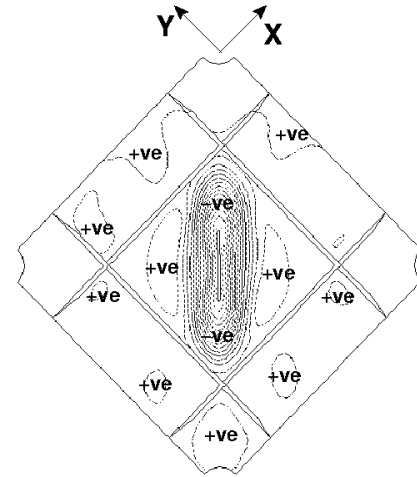

(b) $\mathrm{P}=7,109 \mathrm{lbs}$

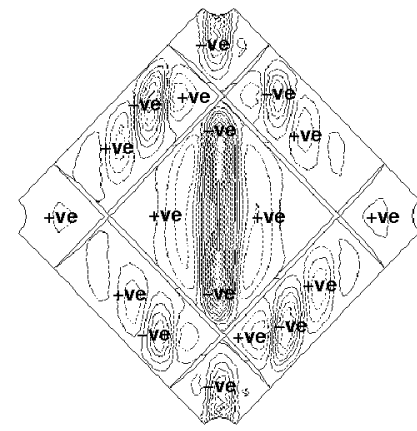

(e) $\mathrm{P}=31,091 \mathrm{lbs}$

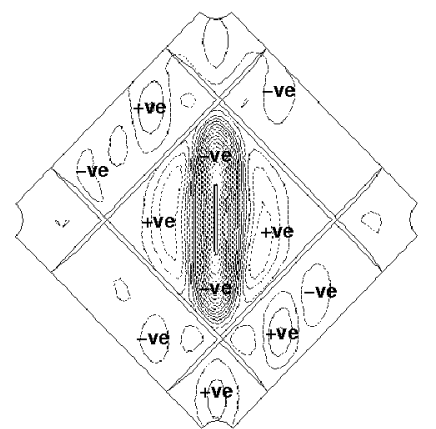

(c) $\mathrm{P}=13,785 \mathrm{lbs}$

FIGURE 10. Analytical out-of-plane displacement contour plots for the notched panel.

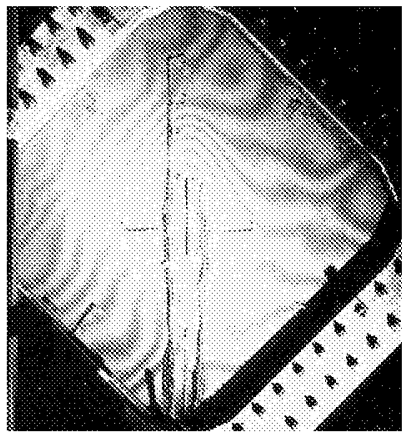

(a) $\mathrm{P}=4,000 \mathrm{lbs}$

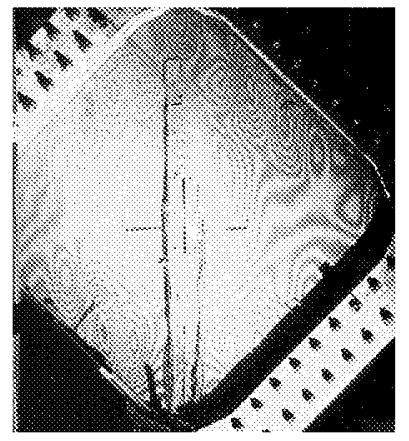

(d) $\mathrm{P}=25,000 \mathrm{lbs}$

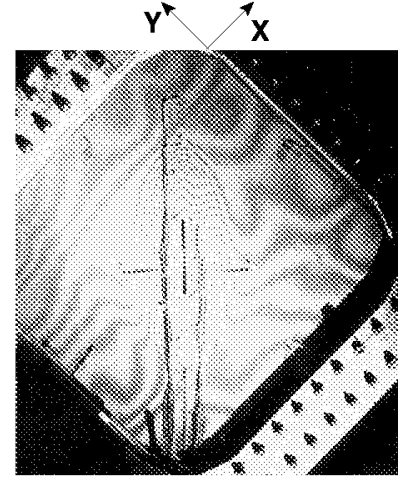

(b) $\mathrm{P}=7,000 \mathrm{lbs}$

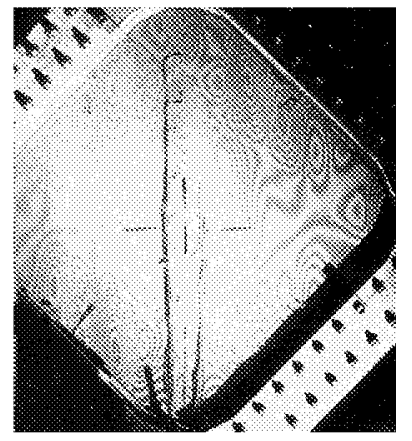

(e) $\mathrm{P}=30,000 \mathrm{lbs}$

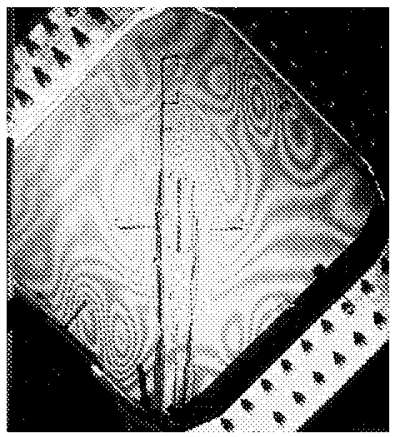

(c) $\mathbf{P}=14,000 \mathrm{lbs}$

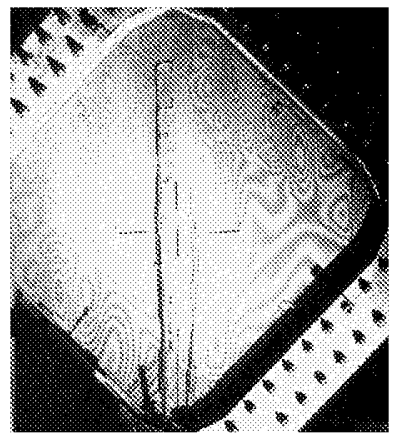

(f) $\mathrm{P}=36,300 \mathrm{lbs}$

FIGURE 11. Experimental out-of-plane displacement contour plot for the notched panel. 


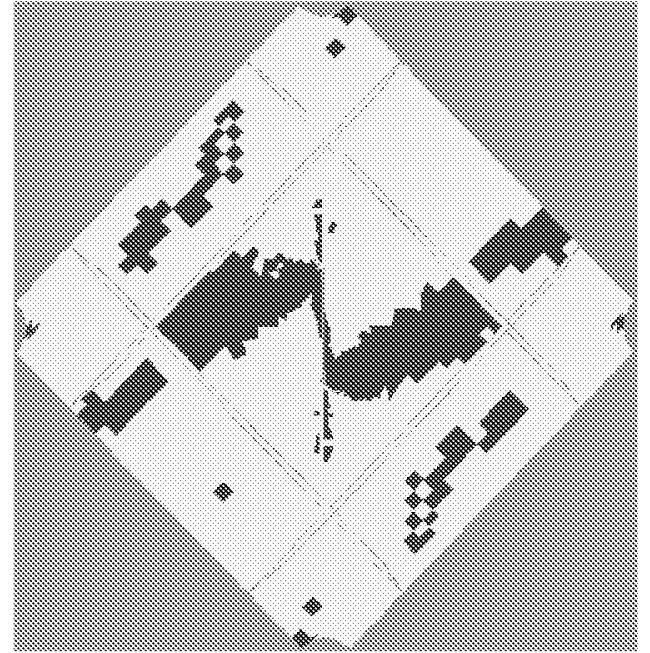

(a) Matrix cracking in the bottom $0^{\circ}$ ply

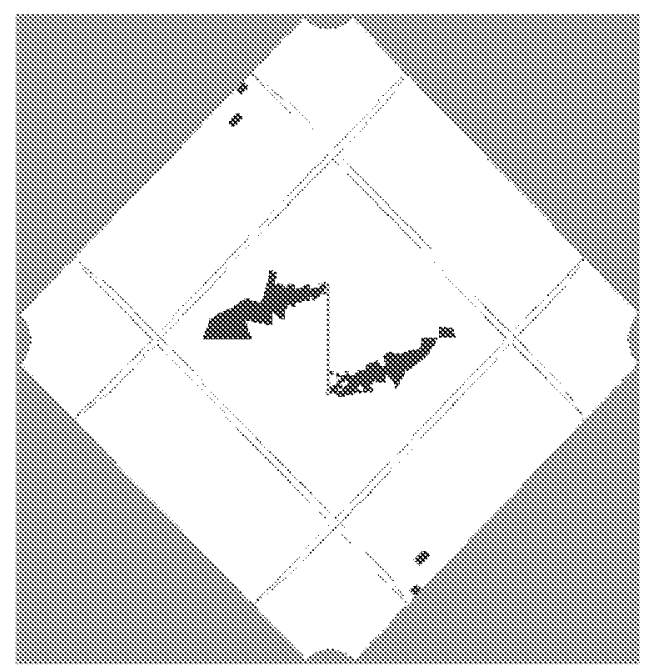

(c) Fiber failure in the bottom $45^{\circ}$ ply

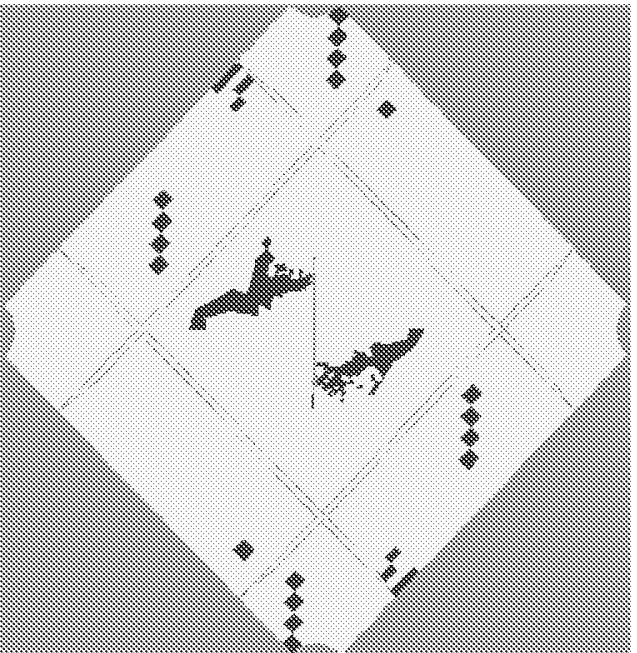

(b) Fiber-matrix shear in the bottom $-45^{\circ}$ ply

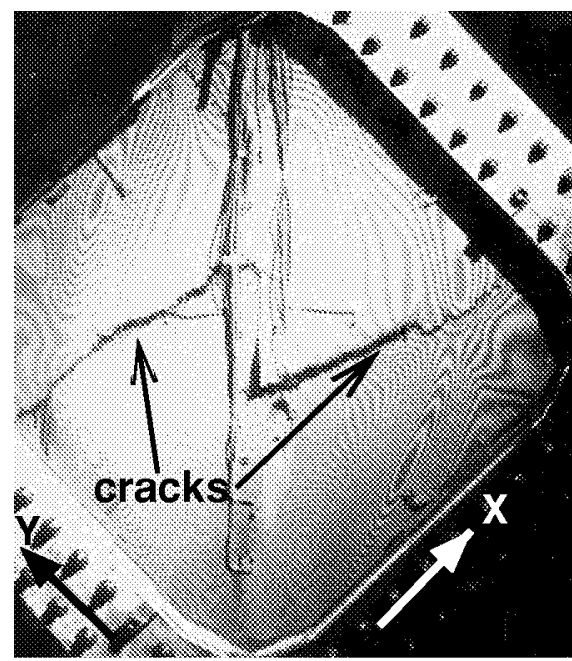

(d) Observed damage

FIGURE 12. Comparison of analytical damage plot and observed damage results for notched panel.
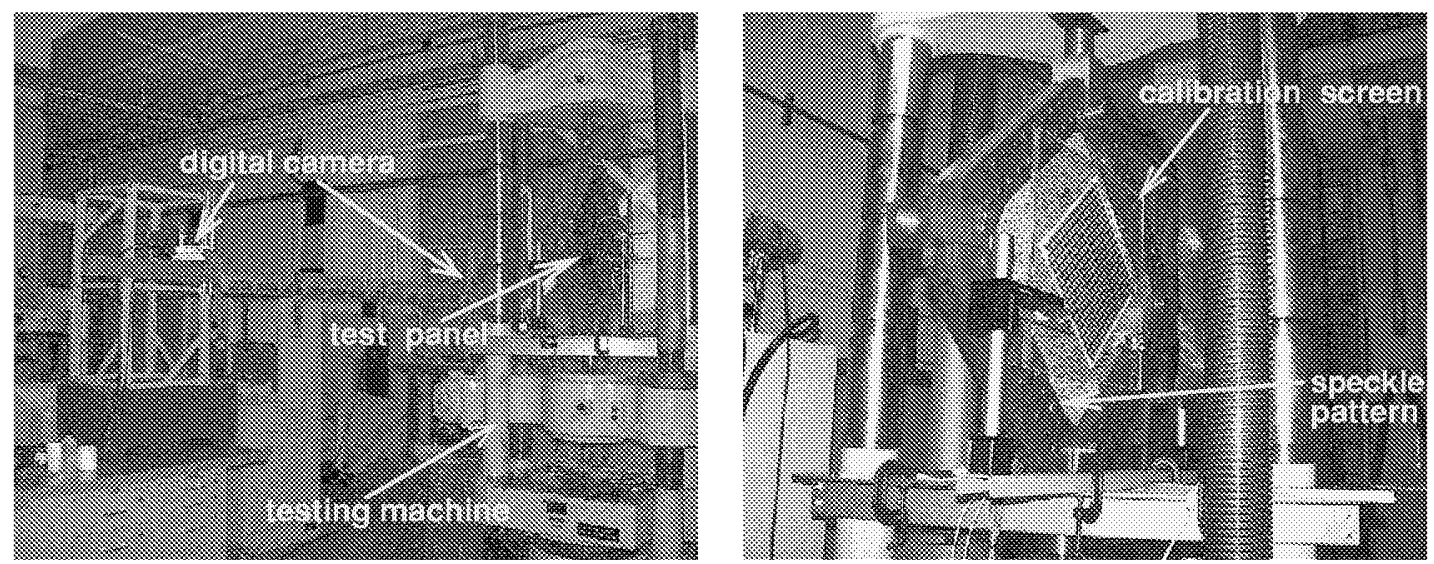

FIGURE 13. Video Image Correlation in 3-D (VIC-3D) arrangement for un-notched panel. 


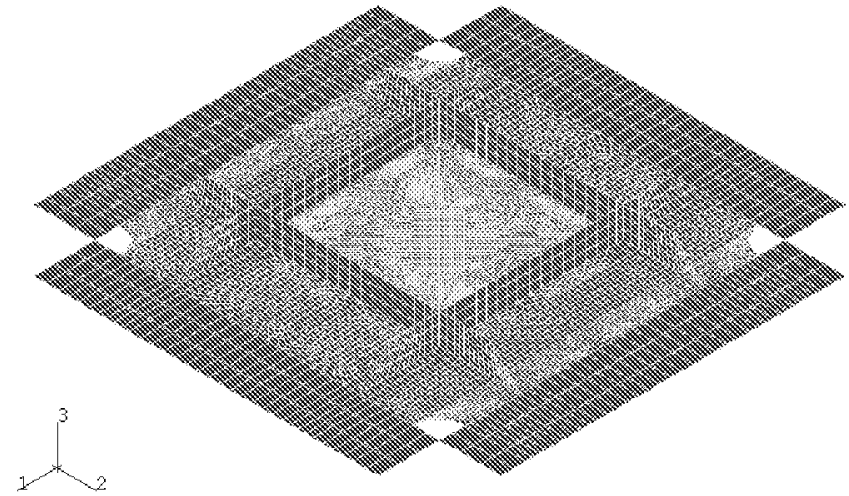

(a) Full model

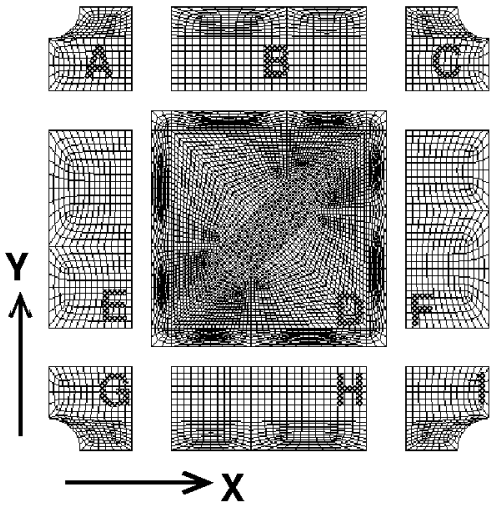

(b) Skin segment model

FIGURE 14. Finite element model of the un-notched panel.

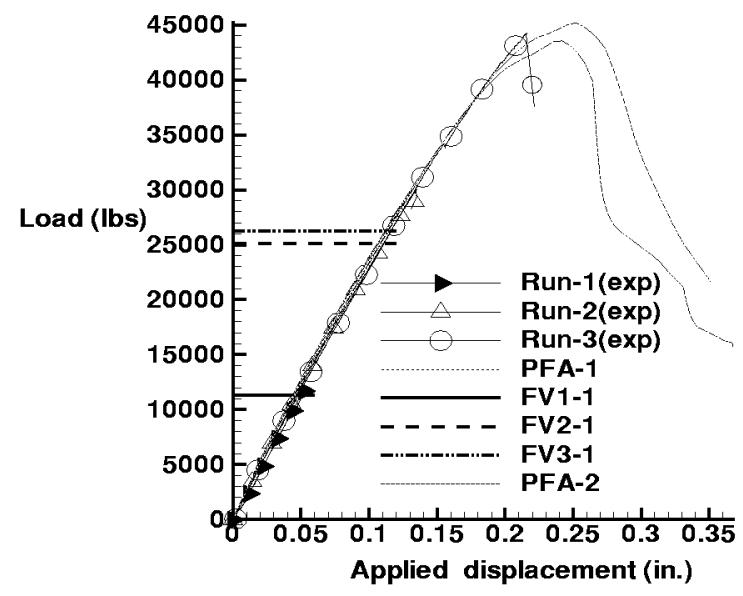

FIGURE 15. Load versus applied displacement results for the un-notched panel.

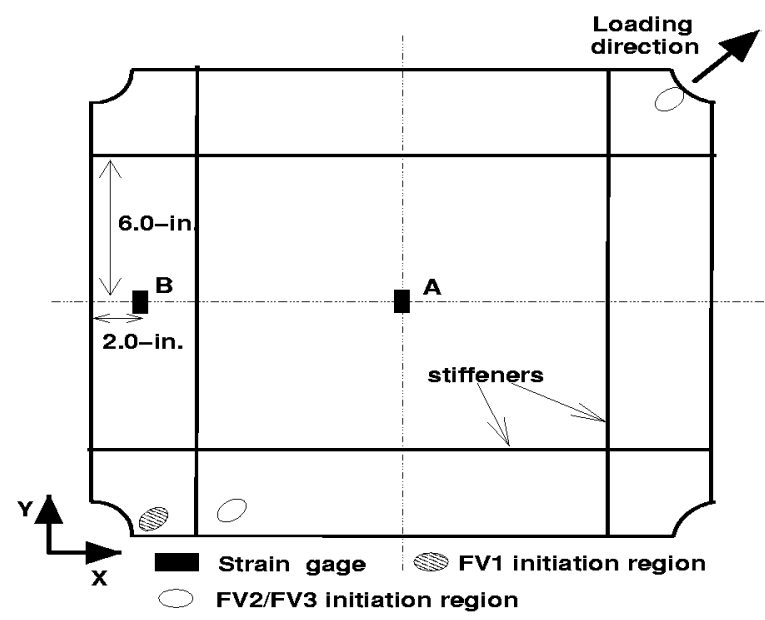

FIGURE 16. Location of some response measurement points on the un-notched panel. 


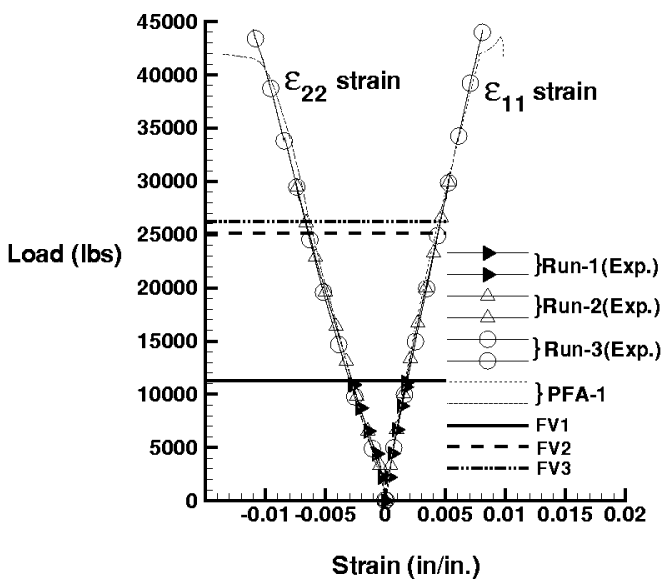

(a) PFA-1

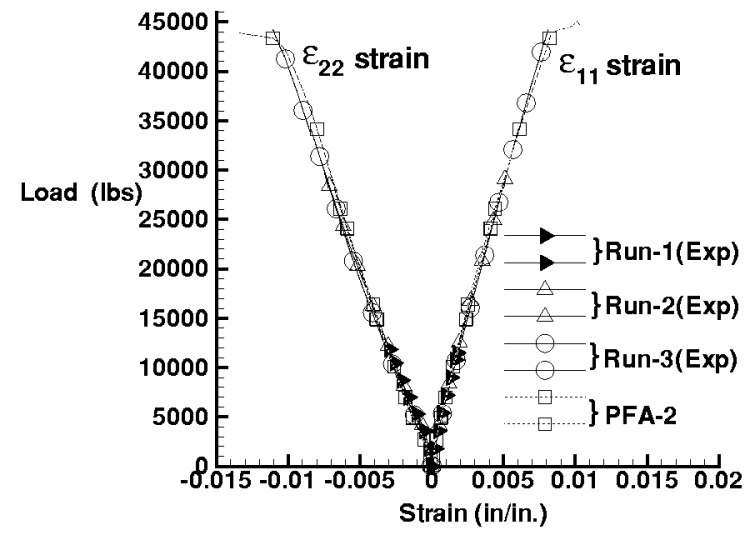

(b) PFA-2

FIGURE 17. Strain results at Location A (Figure 16) for the un-notched panel.

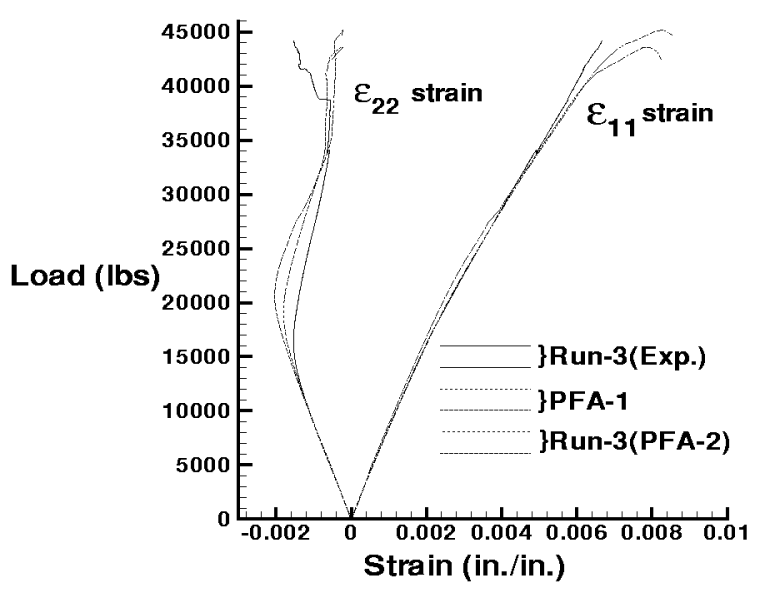

FIGURE 18. Strain results at Location B (Figure 16) for the un-notched panel.

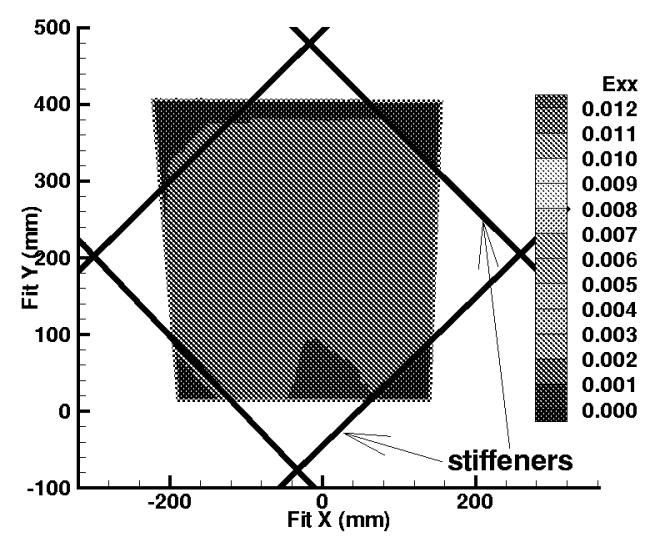

(a) VIC-3D

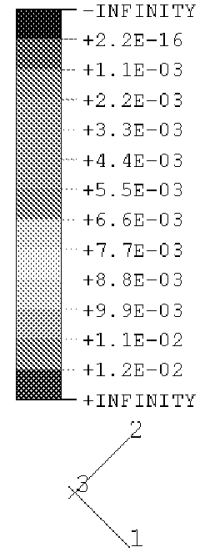

(b) ABAQUS

FIGURE 19. Strain ( $\left.\epsilon_{11}\right)$ field at approximately 11,700 lbs (Run-1) for the un-notched panel. 


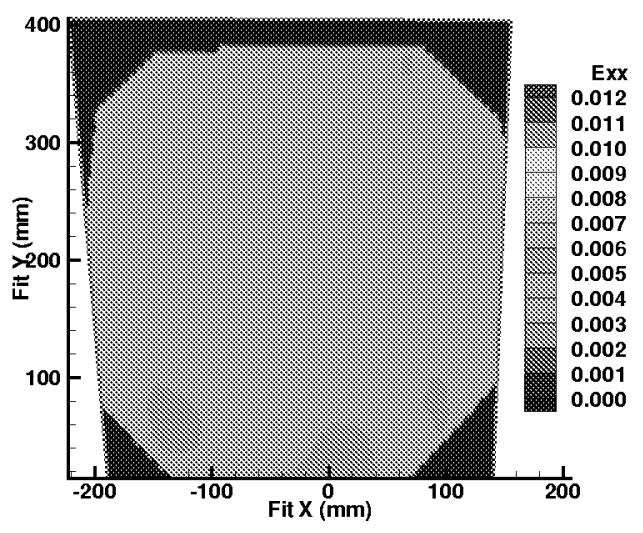

(a) VIC-3D
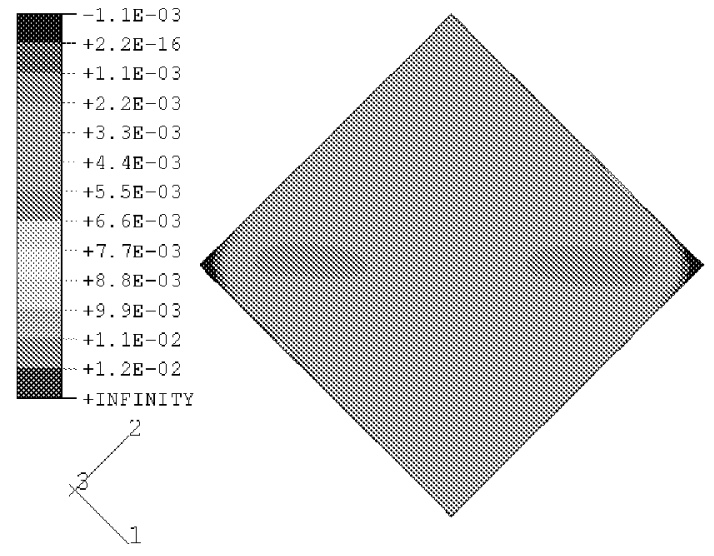

(b) ABAQUS

FIGURE 20. Strain ( $\left.\epsilon_{11}\right)$ field at approximately 30,000 lbs (Run-2) for un-notched panel.

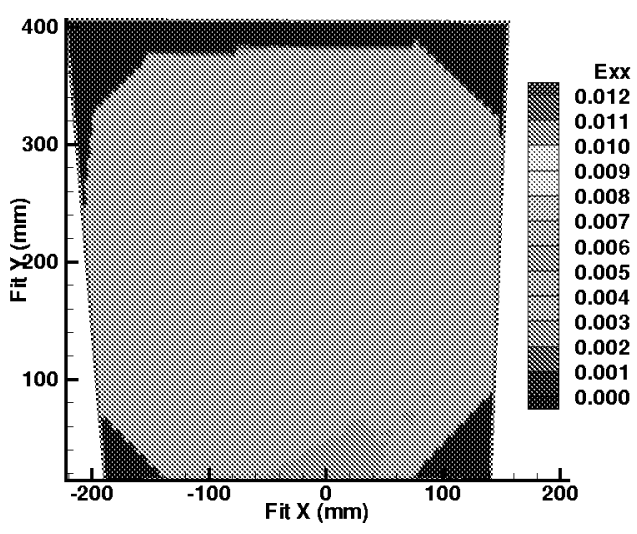

(a) VIC-3D

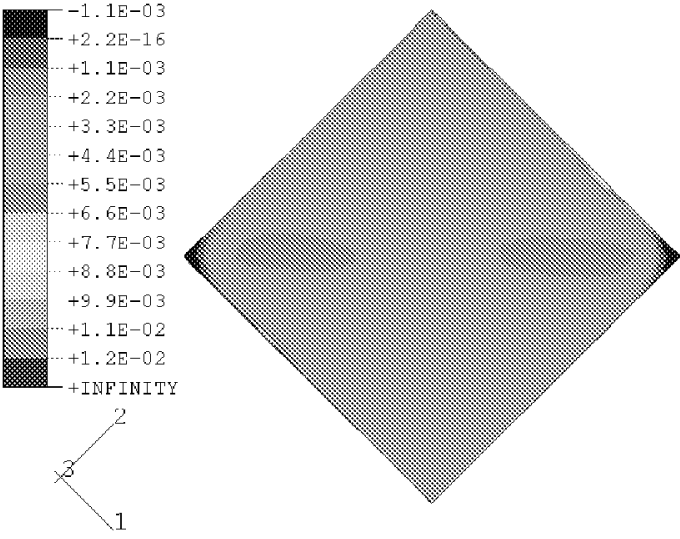

(b) ABAQUS

FIGURE 21. Strain ( $\left.\epsilon_{11}\right)$ field at approximately 30,000 lbs (Run-3) for the un-notched panel.

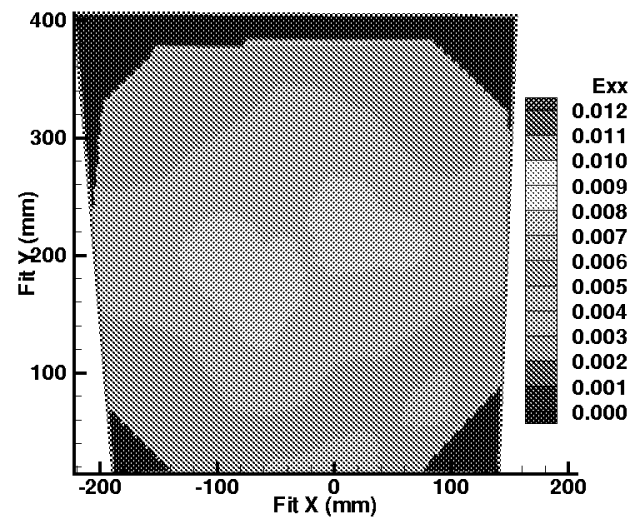

(a) VIC-3D

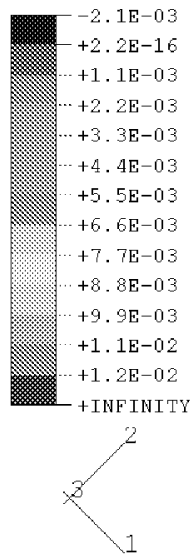

(b) ABAQUS

FIGURE 22. Strain ( $\left.\epsilon_{11}\right)$ field at approximately 44,000 lbs (Run-3) for the un-notched panel. 


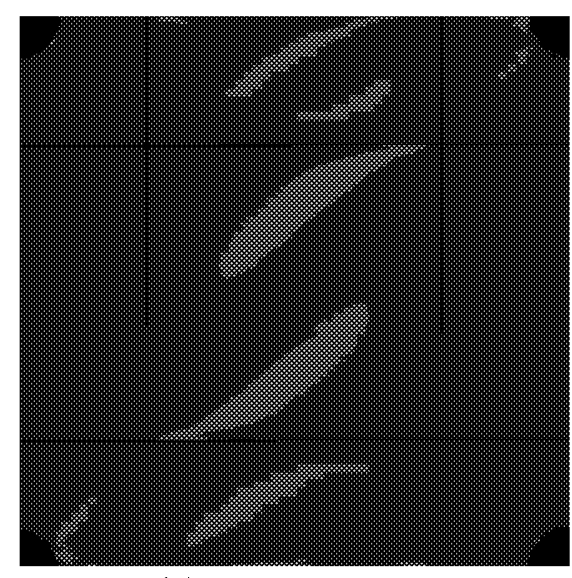

(a) Top 0 deg. ply

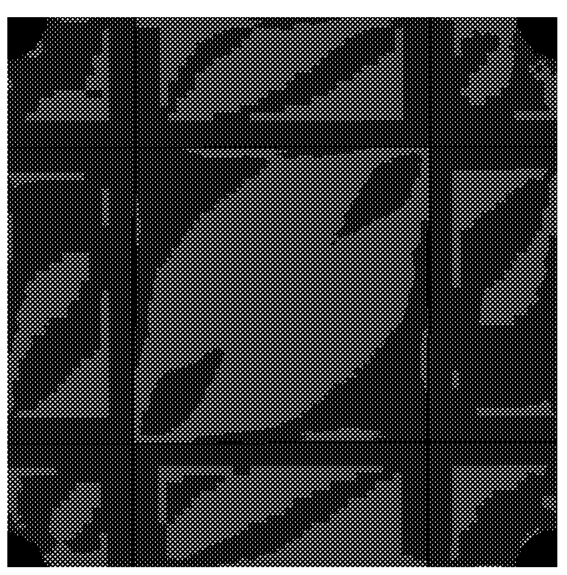

(b) Top -45 deg. ply

FIGURE 23. Fringe plot of matrix cracking damage at approximately 30,000 lbs (Run-2) for the un-notched panel.

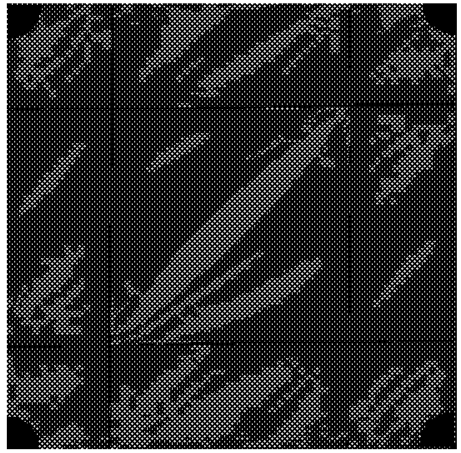

(a) Bottom 45 deg. ply

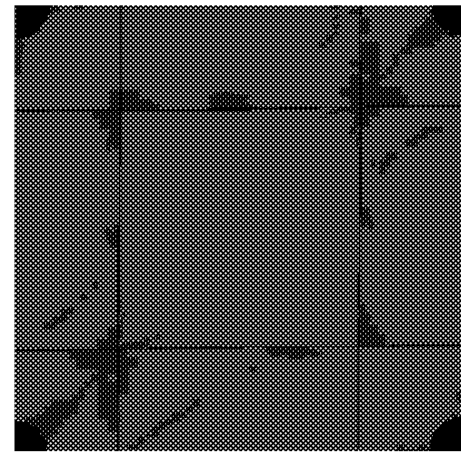

(b) Bottom -45 deg. ply

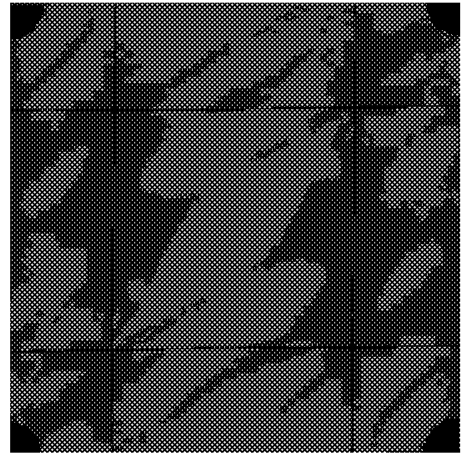

90 deg. ply

FIGURE 24. Fringe plot of matrix cracking damage after failure (Run-3) for the un-notched panel.

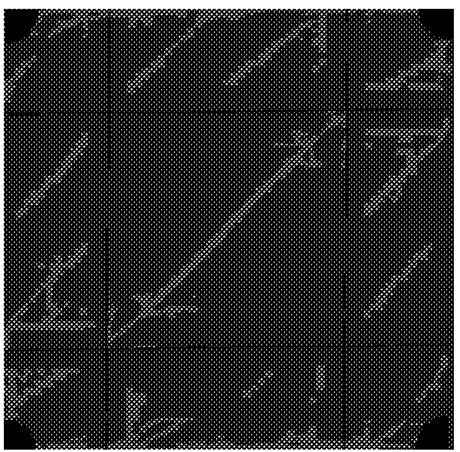

(a) Fiber-matrix shear

in the top -45 deg. ply

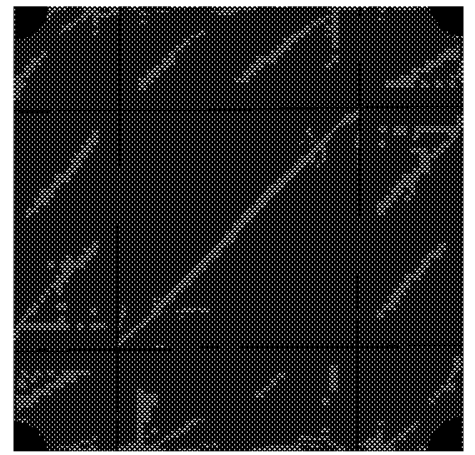

(b) Fiber failure in

the top -45 deg. ply

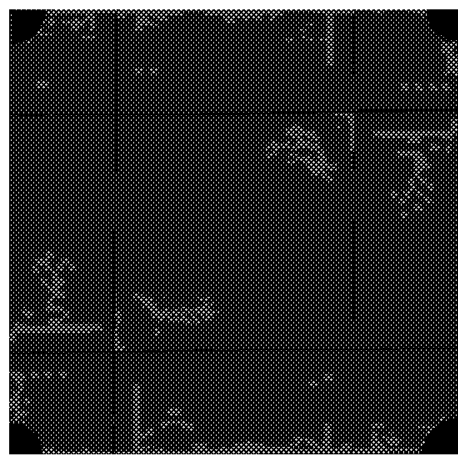

(c) Fiber failure in the top 45 deg. ply

FIGURE 25. Fringe plot of FV2 and FV3 damage after failure (Run-3) for the un-notched panel. 


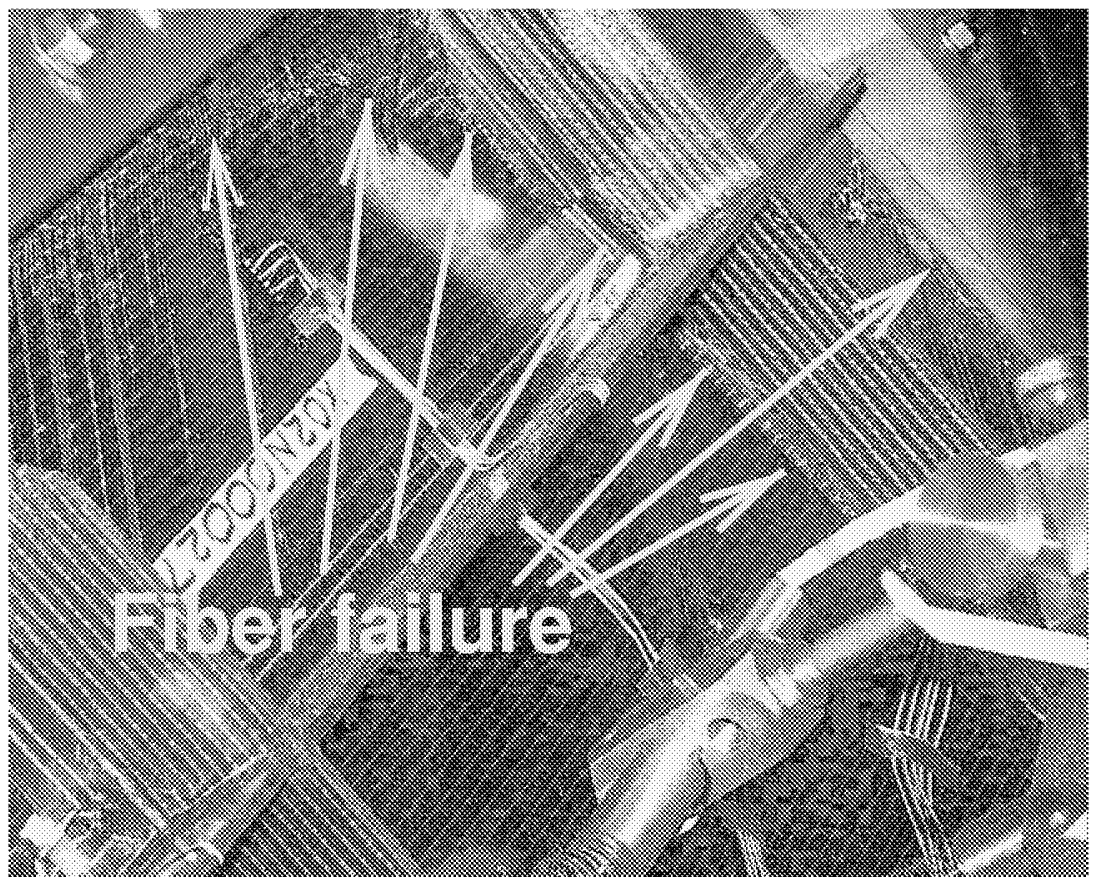

(a) Visual inspection

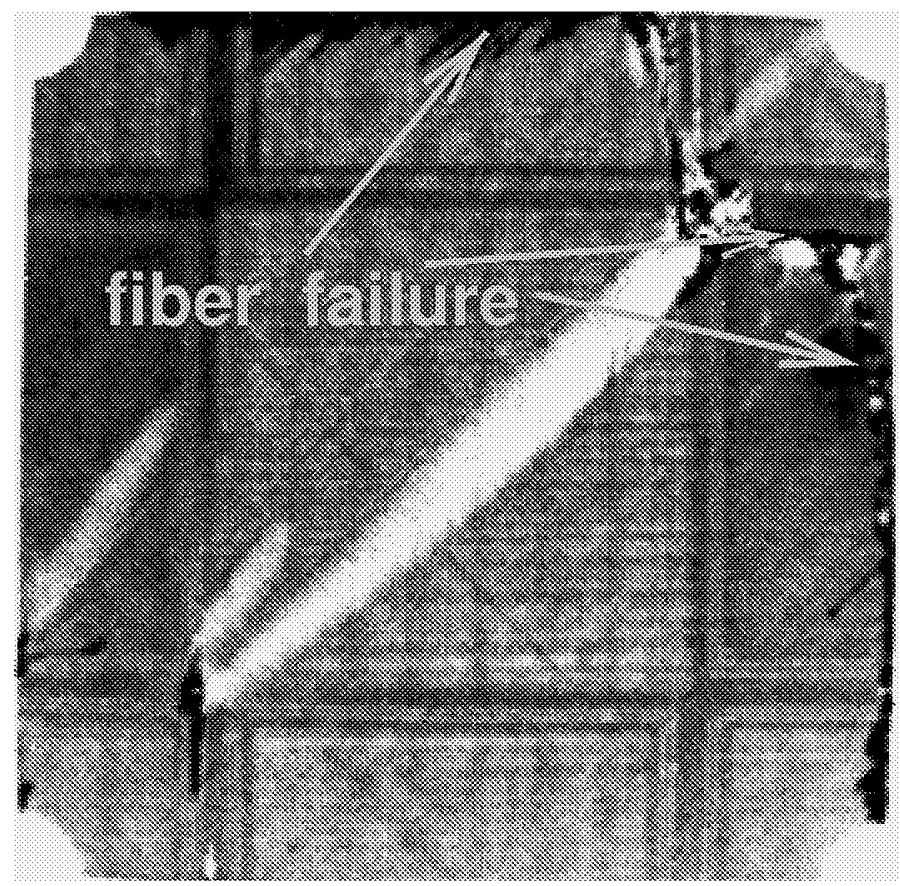

(b) Thermographic scan

FIGURE 26. Observed damage after final failure of the un-notched panel. 


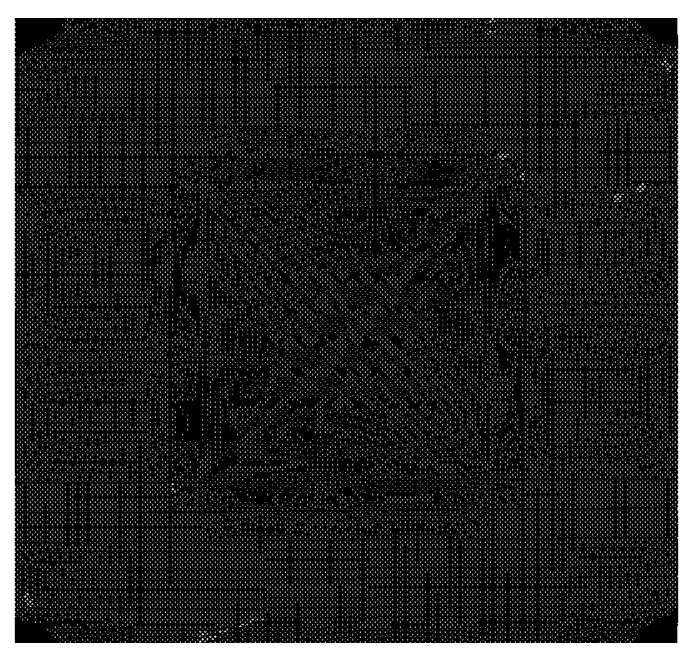

(a) Analytical fiber failure damage plot in the top 45 degree ply at 44.1 kips for the un-notched panel

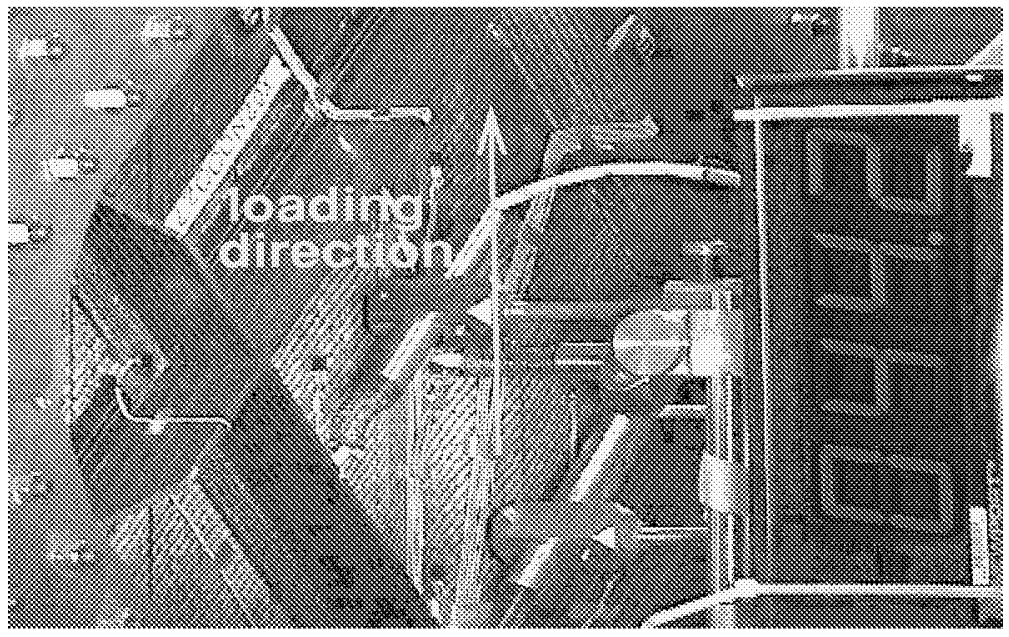

(b) No visible damage

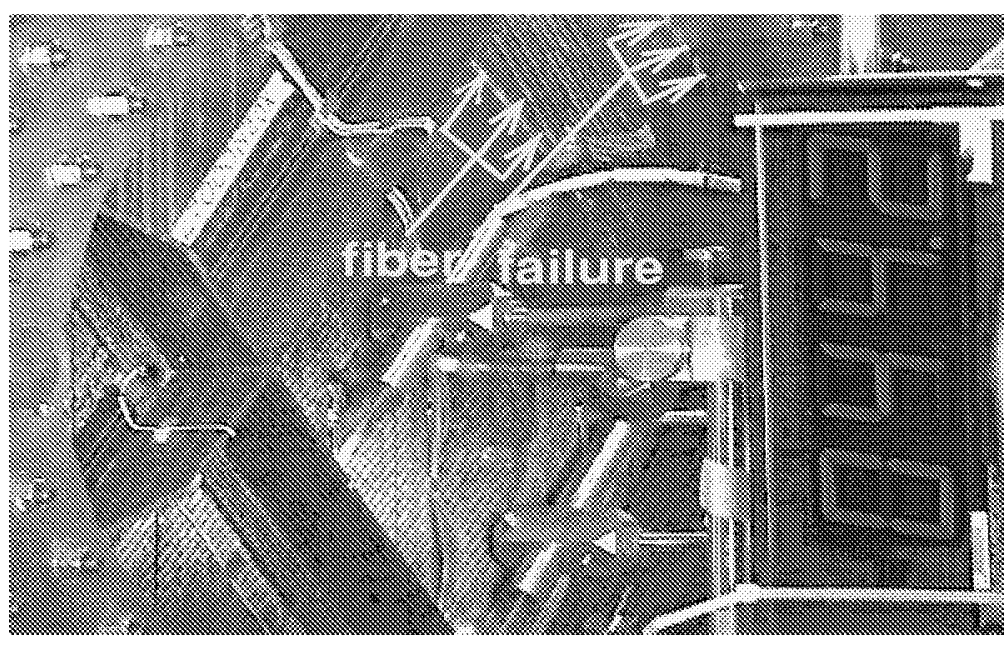

(c) Fiber failure damage

FIGURE 27. Contribution of fiber failure damage to catastrophic failure of the unnotched panel. 


\begin{tabular}{|c|c|c|c|}
\hline \multicolumn{3}{|c|}{ REPORT DOCUMENTATION PAGE } & $\begin{array}{l}\text { Form Approved } \\
\text { OMB No. 0704-0188 }\end{array}$ \\
\hline \multicolumn{4}{|c|}{$\begin{array}{l}\text { Public reporting burden for this collection of information is estimated to average } 1 \text { hour per response, including the time for reviewing instructions, searching existing data sources, } \\
\text { gathering and maintaining the data needed, and completing and reviewing the collection of information. Send comments regarding this burden estimate or any other aspect of this } \\
\text { collection of information, including suggestions for reducing this burden, to Washington Headquarters Sevvices, Directorate for Information Operations and Reports, } 1215 \text { Jefferson } \\
\text { Davis Highway, Suite 1204, Arlingtong VA 22202-4302, and to the Office of Management and Budget, Paperwork Reduction Project (0704-0188), Washington, DC 20503. }\end{array}$} \\
\hline 1. AGENCY USE ONLY(Leave blank) & $\begin{array}{l}\text { 2. REPORT DATE } \\
\text { August } 2002\end{array}$ & \multicolumn{2}{|c|}{$\begin{array}{l}\text { 3. REPORT TYPE AND DATES COVERED } \\
\text { Contractor Report }\end{array}$} \\
\hline \multicolumn{3}{|c|}{$\begin{array}{l}\text { 4. TITLE AND SUBTITLE } \\
\text { PROGRESSIVE FAILURE STUDIES OF STIFFENED PANELS } \\
\text { SUBJECTED TO SHEAR LOADING }\end{array}$} & \multirow[t]{2}{*}{$\begin{array}{l}\text { 5. FUNDING NUMBERS } \\
\text { C NAS1-97046 } \\
\text { WU } 505-90-52-01\end{array}$} \\
\hline \multicolumn{3}{|c|}{$\begin{array}{l}\text { 6. AUTHOR(S) } \\
\text { Damodar R. Ambur, Navin Jaunky, and Mark W. Hilburger }\end{array}$} & \\
\hline \multicolumn{2}{|c|}{$\begin{array}{l}\text { 7. PERFORMING ORGANIZATION NAME(S) AND ADDRESS(ES) } \\
\text { ICASE } \\
\text { Mail Stop } 132 \mathrm{C} \\
\text { NASA Langley Research Center } \\
\text { Hampton, VA } 23681-2199\end{array}$} & & $\begin{array}{l}\text { 8. PERFORMING ORGANIZATION } \\
\text { REPORT NUMBER } \\
\text { ICASE Report No. } 2002-24\end{array}$ \\
\hline \multicolumn{2}{|c|}{$\begin{array}{l}\text { 9. SPONSORING/MONITORING AGENCY NAME(S) AND ADDRESS(E } \\
\text { National Aeronautics and Space Administration } \\
\text { Langley Research Center } \\
\text { Hampton, VA 23681-2199 }\end{array}$} & $\begin{array}{l}\text { 10. SPONS } \\
\text { AGENC } \\
\text { NASA } \\
\text { ICASI }\end{array}$ & $\begin{array}{l}\text { 10. SPONSORING/MONITORING } \\
\text { AGENCY REPORT NUMBER } \\
\text { NASA/CR-2002-211757 } \\
\text { ICASE Report No. } 2002-24\end{array}$ \\
\hline \multicolumn{4}{|c|}{$\begin{array}{l}\text { 11. SUPPLEMENTARY NOTES } \\
\text { Langley Technical Monitor: Dennis M. Bushnell } \\
\text { Final Report } \\
\text { To be submitted to Composite Structures. }\end{array}$} \\
\hline \multicolumn{2}{|c|}{$\begin{array}{l}\text { 12a. DISTRIBUTION/AVAILABILITY STATEMENT } \\
\text { Unclassified-Unlimited } \\
\text { Subject Category } 34 \\
\text { Distribution: Nonstandard } \\
\text { Availability: NASA-CASI (301) 621-0390 }\end{array}$} & 12b. DISTI & 12b. DISTRIBUTION CODE \\
\hline \multicolumn{4}{|c|}{$\begin{array}{l}\text { 13. ABSTRACT (Maximum } 200 \text { words) } \\
\text { Experimental and analytical results are presented for progressive failure of stiffened composite panels with and } \\
\text { without a notch and subjected to in-plane shear loading well into their postbuckling regime. Initial geometric } \\
\text { imperfections are included in the finite element models. Ply damage modes such as matrix cracking, fiber-matrix } \\
\text { shear, and fiber failure are modeled by degrading the material properties. Experimental results from the test include } \\
\text { strain field data from video image correlation in three dimensions in addition to other strain and displacement } \\
\text { measurements. Results from nonlinear finite element analyses are compared with experimental data. Good agreement } \\
\text { between experimental data and numerical results are observed for the stitched stiffened composite panels studied. }\end{array}$} \\
\hline \multirow{2}{*}{\multicolumn{3}{|c|}{$\begin{array}{l}\text { 14. SUBJECT TERMS } \\
\text { composite structures, progressive failure, ply damage mode, buckling, postbuckling, } \\
\text { video image correlation }\end{array}$}} & $\begin{array}{l}\text { 15. NUMBER OF PAGES } \\
25\end{array}$ \\
\hline & & & $\begin{array}{c}\text { 16. PRICE CODE } \\
\text { A03 }\end{array}$ \\
\hline $\begin{array}{l}\text { 17. SECURITY CLASSIFICATION } \\
\text { OF REPORT } \\
\text { Unclassified }\end{array}$ & $\begin{array}{l}\text { 18. SECURITY CLASSIFICATION } \\
\text { OF THIS PAGE } \\
\text { Unclassified }\end{array}$ & $\begin{array}{l}\text { 19. SECURITY CLASSIFICATION } \\
\text { OF ABSTRACT }\end{array}$ & $\begin{array}{l}\text { 20. LIMITATION } \\
\text { OF ABSTRACT }\end{array}$ \\
\hline
\end{tabular}

